\title{
Influences of Cognitive Representations of Cancer on Emotional Responses and Coping Strategies With Relation to Their Comfort Level Among Breast Cancer Women
}

\author{
Deeplata Mendhem ${ }^{1}$, Abhay Mudey ${ }^{2}$ and Seema Singh ${ }^{3}$ \\ ${ }^{1,2,3}$ Community Health Nursing, SRMM College of Nursing, Sawangi (Meghe), Wardha \\ Department of Community Medicine, Jawaharlal Nehru Medical College \\ Srmmcon, Sawangi Meghe, Wardha, India
}

\section{ABSTRACT}

Cancer remains a life-threatening situation and often has profound emotional impact even years after treatment has started. Emotional distress is considered a normal response around the time of cancer diagnosis. It is also common across the cancer trajectory with many patients in treatment or long-term follow-up reporting clinically significant levels of distress, including anxiety and depression. 1 To evaluate the coping strategies used by the women having breast cancer .2. To identify the correlation between the stages of cancer and coping strategies among the women having breast cancer. 3. To identify the correlation between coping strategies among the women having breast cancer.4. To find out association between the coping strategies with selected demographical variables among the women having breast cancer. The nature and extent of coping strategies used by the participants showed that in the first interview 95.6\% reported facing life threatening diagnosis which increased to $96.4 \%$ in the second and to $96.8 \%$ in the third interview. During the first interview 90.8\% had their lines of communication open which increased to 95.2\% in second interview and then slightly reduced to $94.4 \%$ in the third interview. In the first interview 95.6\% anticipated physical changes which increased to $99.2 \%$ in the second interview and reduced to $98.4 \%$ in the third interview. Among the participants, $85.2 \%$ reported of maintaining a healthy lifestyle in the first interview which increased to $93.6 \%$ in the second interview but gradually reduced to $92.8 \%$ in third interview. 92.8\% reported of getting help from their family and friends in the first interview which increased to $98.4 \%$ in the second interview and again came down to $97.6 \%$ in the third interview. Regarding psychological pain; $1.2 \%$ reported the pain of facing the stigma in first interview which remained constant in second interview with a minimal increase to $1.6 \%$ in the third interview. Self-blame was common with 73.6\% reporting of blaming self in the first interview which reduced to 69.9\% in the second interview and again increased to $72 \%$ in third interview. Among the study participants 30.4\% had reported of being religious which remained constant in second interview but reduced to $27.2 \%$ in the third interview. During the second interview which was 1 month after the first interview the use of coping strategies had increased which reduced again in third interview which was again after 2 months after the first interview. This indicates that the use of coping strategies was fluctuating. The study participants used a wide range of coping strategies to a variable extent.

\section{KEY WORDS: COGNITIVE REPRESENTATIONS, COPING STRATEGIES}

\section{INTRODUCTION}

Newly diagnosed breast cancer patients display high levels of distress, and loss of effectiveness in key cognitive

Biosc Biotech Res Comm P-ISSN: 0974-6455 E-ISSN: 2321-4007

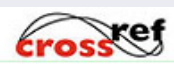

Identifiers and Pagination

Year: 2021 Vol: 14 No (9) Special Issue

Pages: $150-157$

This is an open access article under Creative

Commons License Attribn 4.0 Intl (CC-BY).

DOI: $h t t p: / / d x . d o i . o r g / 10.21786 / b b r c / 14.9 .29$ activities, increasing concern over the psychological impact of being offered a role in decision making for treatment. The extent to which patients are affected by their emotional reaction to their diagnosis may be closely related to their ability to plan their medical care.

Need of the Study: Fear of uncertainty, intense emotional reactions to diagnosis and time pressures to take treatment, decision can leave women feeling overwhelmed. In such a mental state they are unable to process the information or take on the responsibility in decision making. To make an informed choice, patients have to digest a lot of
Article Information

Received: $15^{\text {th }}$ Apr 2021

ccepted after revision: $29^{\text {th }}$ June 2021 
information, and the way in which it is presented may impact on the decision they make.

Statement: Influences of cognitive representations of cancer on emotional responses and coping strategies with relation to their comfort level among breast cancer women.

AIM: Evaluating the influences of cognitive representations of cancer on coping strategies at all stages of cancer that is first, second and third stage among breast cancer women.

\section{Objectives}

1. To evaluate the coping strategies used by the women having breast cancer

2. To identify the correlation between the stages of cancer and coping strategies among the women having breast cancer.

3. To identify the correlation between coping strategies among the women having breast cancer.

4. To find out association between the coping strategies with selected demographical variables among the women having breast cancer.

Sample Size: The sample size in this study was 250 women suffering from various stages of breast cancer except fourth stage of cancer.

\section{Variables}

The variables under study were -

Dependent variables: Cognitive representations on coping strategies of women suffering from breast cancer.

Independent variable: Breast cancer

Review of Literture: Literature related to coping strategies used by breast cancer women A Research study conducted in Bangalore among the cancer patients who were receiving radiation therapy showed that ineffective coping mechanisms such as, helplessness and fatalism were leading to incomplete resolution. Interventions to minimize these concerns and handle the associated anxiety, depression would improve their quality of life. A variety of coping skills are required to adjust to and life successfully with cancer. One's ability to cope affects how one perceives or appraises the situation, how well one relates to others and how one can manage side effects of treatment, including pain. Patients who cope effectively are being able to accept a diagnosis, seek more information, talk with others to relieve stress and undertake some positive, constructive action.

A study reported that problem-focused coping strategies, such as cognitive acceptance, positive and constructive thinking, and using emotional support and religion were mostly considered as beneficial coping strategies. The results indicated that trying to be hopeful and trying to have a positive, optimistic perspective and cognitive acceptance have very important roles among young women who are married and having children with breast cancer.

\section{Methodology}

- Research Setting: The study was conducted in the selected multidisciplinary hospitals of Wardha, Maharashtra.

- Study Design:Analytical Survey

- Participants: Adult women with breast cancer who had undergone chemotherapy and mastectomy in the age group of 20 years to 62 years and in between the diagnosis of any three stages, first, second and third.

- Sampling Techniques:Purposive Sampling technique.

Material with their standardization: The tools used for data collection were modified standardized tools. The tools used in this study includes

1. Demographic data sheet:

2. Cognitive assessment tool: It includes the cognition of breast cancer patient related to their experiences and suffering with the disease.

3. To assess the coping strategies of breast cancer women Brief Coping Orientations to Problems Experienced Inventory (Brief COPE) (Carver, 1997) was modified according to Indian setting and utilized.

\section{Eligibility Criteria:}

\section{Inclusion Criteria includes:}

- Women who have been diagnosed with I to III stage of breast cancer and are under treatment.

- Women aged 18 years and above.

- Who are willing to participate in the study

- Exclusion criteria includes

- Women with alteration of consciousness.

- Women who have previous history of other cancer.

- Women with mental illness.

- Breast cancer women who are at fourth stage (Metastasis).

\section{Analysis and Deliberations:}

Part I: Demographic distribution of the participants

Part II: Cognitive levels of study participants regarding breast cancer

Part III: Correlation between the nature of coping strategies by the participants.

Part IV: Correlation between the stages of cancer and their coping strategies among the women having breast cancer.

Part V: Level of significance difference in the coping 
strategies of the participants in three different the demographic variables. interviews

Part I: Demographic distribution of the study

Part VI: Association of nature of coping strategies with participants

Table 1. Distribution of Participants according to their Demographic Characteristics $N=250$

\begin{tabular}{|c|c|c|c|c|}
\hline S. N. & Demographic Characteristics & Categories & Freq. & $\%$ \\
\hline 1 & Age in Years & $\begin{array}{l}\cdot 20-30 \\
\bullet 31-40 \\
\bullet 41-50 \\
\bullet 51-60 \\
\bullet 61-70 \\
\bullet>70\end{array}$ & $\begin{array}{l}37 \\
48 \\
94 \\
70 \\
01 \\
00\end{array}$ & $\begin{array}{c}14.8 \\
19.2 \\
37.6 \\
28 \\
0.4 \\
0\end{array}$ \\
\hline 2 & Residence & $\begin{array}{c}\text { •Urban } \\
\text { •Rural } \\
\text { •Semi-urban }\end{array}$ & $\begin{array}{c}167 \\
51 \\
32\end{array}$ & $\begin{array}{l}66.8 \\
20.4 \\
12.8\end{array}$ \\
\hline 3 & Education & $\begin{array}{c}\text {-Illiterate } \\
\text {-Primary } \\
\text {-Secondary } \\
\text { •Higher Secondary } \\
\text {-Graduation } \\
\text {-PG or Other }\end{array}$ & $\begin{array}{c}49 \\
55 \\
77 \\
44 \\
23 \\
2\end{array}$ & $\begin{array}{c}19.6 \\
22 \\
30.8 \\
17.6 \\
9.2 \\
0.8\end{array}$ \\
\hline 4 & Occupation & $\begin{array}{l}\bullet \text { Farmers } \\
\bullet \text { Homemakers } \\
\bullet \text { Private Service } \\
\text {-Govt. Service } \\
\text {-Students }\end{array}$ & $\begin{array}{c}52 \\
58 \\
111 \\
25 \\
4\end{array}$ & $\begin{array}{c}20.8 \\
23.2 \\
44.4 \\
10 \\
1.6\end{array}$ \\
\hline 5 & $\begin{array}{l}\text { Monthly Family } \\
\text { Income in Rupees }\end{array}$ & •Less than $10000 /-$ & 32 & 12.8 \\
\hline & & $\begin{array}{l}\bullet 10001-20000 /- \\
\bullet 20001-30000 /- \\
\bullet \text { More than 30001/- }\end{array}$ & $\begin{array}{l}73 \\
48 \\
97\end{array}$ & $\begin{array}{l}29.2 \\
19.2 \\
38.8\end{array}$ \\
\hline 6 & Age of Menarche & $\begin{array}{c}\bullet \text { Less than } 10 \text { yrs. } \\
\bullet 10-12 \text { yrs. } \\
\bullet 13-15 \text { yrs. } \\
\bullet \text { More than } 15 \text { yrs. }\end{array}$ & $\begin{array}{c}0 \\
1 \\
210 \\
39\end{array}$ & $\begin{array}{c}0 \\
0.4 \\
84 \\
15.6\end{array}$ \\
\hline 7 & Marital Status & $\begin{array}{c}\bullet \text { Unmarried } \\
\bullet \text { Married } \\
\bullet \text { Widow/Separated/Divorced }\end{array}$ & $\begin{array}{c}8 \\
197 \\
45\end{array}$ & $\begin{array}{c}3.2 \\
78.8 \\
18\end{array}$ \\
\hline 8 & Years of marriage & $\begin{array}{c}\bullet \text { Not Applicable } \\
\bullet \text { Less than } 10 \text { yrs. } \\
\bullet 10-20 \text { yrs. } \\
\bullet 21-30 \text { yrs. } \\
\bullet \text { More than } 30 \text { yrs. }\end{array}$ & $\begin{array}{c}8 \\
19 \\
45 \\
78 \\
100\end{array}$ & $\begin{array}{c}3.2 \\
7.6 \\
18 \\
31.2 \\
40\end{array}$ \\
\hline 9 & Number of children & $\begin{array}{c}\text { •Not Applicable } \\
\bullet \text { No children } \\
\text { •One } \\
\text { •Two } \\
\text { •Three } \\
\text { •More than } 3\end{array}$ & $\begin{array}{c}8 \\
20 \\
48 \\
78 \\
57 \\
39\end{array}$ & $\begin{array}{c}3.2 \\
8 \\
19.2 \\
31.2 \\
22.8 \\
15.6\end{array}$ \\
\hline 10 & History of Breast Feeding & $\begin{array}{c}\bullet \text { Not applicable } \\
\bullet \text { No history of breast feeding } \\
\bullet \text { Regular }\end{array}$ & $\begin{array}{c}8 \\
20 \\
211\end{array}$ & $\begin{array}{c}3.2 \\
8 \\
84.4\end{array}$ \\
\hline
\end{tabular}




\begin{tabular}{|c|c|c|c|c|}
\hline 11 & Type of Family & $\begin{array}{l}\text { •Irregular } \\
\text { •Joint } \\
\text { •Nuclear }\end{array}$ & $\begin{array}{c}11 \\
127 \\
123\end{array}$ & $\begin{array}{r}4.4 \\
50.8 \\
49.2\end{array}$ \\
\hline 12 & Health Insurance & $\begin{array}{l}\bullet \text { Yes } \\
\bullet \text { No }\end{array}$ & $\begin{array}{c}22 \\
228\end{array}$ & $\begin{array}{c}8.8 \\
91.2\end{array}$ \\
\hline 13 & History of Breast Cancer in the family & $\begin{array}{l}\bullet \text { Yes } \\
\bullet \text { No }\end{array}$ & $\begin{array}{c}6 \\
244\end{array}$ & $\begin{array}{c}2.4 \\
97.6\end{array}$ \\
\hline 14 & If yes, relationship with the patient & $\begin{array}{l}\text {-Not Applicable } \\
\text {-Maternal Aunt } \\
\text {-Paternal Aunt } \\
\text {-Granddaughter } \\
\text { •Niece }\end{array}$ & $\begin{array}{c}244 \\
1 \\
2 \\
2 \\
1\end{array}$ & $\begin{array}{c}97.6 \\
0.4 \\
0.8 \\
0.8 \\
0.4\end{array}$ \\
\hline 15 & Duration of Diagnosis & $\begin{array}{l}\bullet \text { Less than one year } \\
\qquad 1-5 \text { yrs. } \\
\bullet 6 \text { - } 10 \text { yrs. } \\
\bullet \text { More than } 10 \text { years }\end{array}$ & $\begin{array}{c}185 \\
65 \\
0 \\
0\end{array}$ & $\begin{array}{c}74 \\
26 \\
0 \\
0\end{array}$ \\
\hline 16 & Current stage of Breast Cancer & $\begin{array}{l}\text {-Stage I } \\
\text { - Stage II } \\
\text { - Stage III }\end{array}$ & $\begin{array}{c}30 \\
188 \\
32\end{array}$ & $\begin{array}{c}12 \\
75.2 \\
12.8\end{array}$ \\
\hline 17 & Line of Treatmentct Management & $\begin{array}{l}\bullet \text { Just Diagnosed \&t no } \\
\text { Treatment started } \\
\bullet \text { Only Chemotherapy } \\
\bullet \text { Only Surgery } \\
\bullet \text { Chemo + Surgery }\end{array}$ & $\begin{array}{c}20 \\
\\
128 \\
65 \\
37\end{array}$ & $\begin{array}{c}8 \\
\\
51.2 \\
26 \\
14.8\end{array}$ \\
\hline 18 & Source of information & $\begin{array}{c}\bullet \text { Mass media } \\
\bullet \text { Health professional } \\
\cdot \text { Family and friends }\end{array}$ & $\begin{array}{c}193 \\
42 \\
15\end{array}$ & $\begin{array}{c}77.2 \\
16.8 \\
6\end{array}$ \\
\hline
\end{tabular}

This part of the study deals with the demographic variables of the samples of the study i.e. age in years, residence, education, occupation, monthly family income, age of menarche, marital status, age of marriage, number of children, history of breast feeding, type of family, health insurance status, family history of breast cancer, if yes, relationship with the patient, duration of diagnosis of breast cancer, current stage of breast cancer, line of treatment and management and source of information. The above table no. 1 reveals that 37(14.8\%) participant were in the age group of $20-30$ years, $48(19.2 \%)$ in the age group of 31-40 years, $94(37.6 \%)$ in the age group of 41-50 years, $70(28 \%)$ in the age group of 51-60 years and there was only $1(0.4 \%)$ in the age group of $61-70$ years. One sixty seven (66.8\%) participant resides in the urban area, $51(20.4 \%)$ resides in the rural area, whereas $32(12.8 \%)$ resides in semi urban area. Forty nine (19.6\%) participants were illiterate, 55(22\%) have primary education, $77(30.8 \%)$ up to secondary, $44(17.6 \%)$ up to higher secondary, 23 (9.2\%) upto graduation and only $2(0.8 \%)$ were upto the post-graduation education.

Fifty two (20.8 \%) participants were farmer, 58(23.8\%) were homemakers, $111(44.4 \%)$ have private service, $25(10 \%)$ have government service, whereas only $4(1.6 \%)$ were students. Thirty two (12.8\%) participants have less than 10,000 rupees monthly income, 73(29.2\%) between 10001-20000 rupees, 48(19.2\%) between the 2000130000 rupees and $97(38.8 \%)$ were having more than 30001 rupees. Only $1(0.4 \%)$ participant was between age group of 10-12 years old of menarche, 210 (84\%) were between age group of 13-15 years old and 39 (15.6\%) were more than 15 years old at menarche. Eight (3.2\%) participants were unmarried, 197(78.8\%) were married and $45(18 \%)$ were from the widow/separated/divorced. Participants who were under the category of less than 10 years of marriage were $19(7.6 \%), 45(18 \%)$ were between $10-20$ years, $78(31.2 \%)$ were in between the $21-30$ years and $100(40 \%)$ were more than 30 years. Eight( $3.2 \%)$ participants were not applicable as they were unmarried, 20(8\%) participants had no children, 48(19.2\%) were having only one child, 78(31.2\%) were having two children, 75(22.8\%) were having three children and $39(15.6 \%)$ were having more than three children.

Eight $(3.2 \%)$ participants were not applicable as they were unmarried, $20(8 \%)$ participants had no history of breast feeding, 211(84.4\%) had given regular breast feeding and 11(4.4\%) had given irregular breast feeding. One hundred twenty seven (50.8\%) participants belongs to joint family and $123(49.2 \%)$ belongs to nuclear family. Twenty two (8.8\%) participants were having health insurance and 228(91.2\%) were not having any health insurance.

Six (2.4\%) participants were having family history of cancer, whereas $244(97.6 \%)$ were not having any family history of cancer. Only $1(0.4 \%)$ participant's maternal aunt had history of cancer, $2(0.8 \%)$ participant's paternal aunt had history of cancer, $2(0.8 \%)$ participant's granddaughter had history of cancer and 1 (0.4\%) participant's niece had history of cancer. One hundred eighty five 
(74\%) participants were diagnosed within less than one year duration and 65(26\%) participants were diagnosed between last 1 to 5 years. Thirty (12\%) participants were at stage I, 188(75.2\%) participants were at stage II and $32(12.8 \%)$ participants were at stage III. Twenty (8\%) participants were just diagnosed and did not receive any treatment, 128(51.2\%) participants were receiving only chemotherapy, 65(26\%) participants have undergone surgery (Mastectomy) and 37 (14.8\%) participants were receiving both chemotherapy and undergone surgery (Mastectomy). One hundred ninety three (77.2\%) participants got the source of information from the mass media and $42(16.8 \%)$ got from the health professional whereas 15(6\%) got information from the family and friends.

\section{Part II: Cognitive levels of study participants regarding breast cancer}

The above table no. 2shows the level of cognitive of study participants regarding breast cancer. It reveals that $17(6.8 \%)$ participants had poor cognitive level, $199(79.6 \%)$ had average cognitive level and only $34(13.6 \%)$ had good cognitive level regarding breast cancer.

\section{Part III: Correlation between the nature of coping strategies by the participants}

The above table No. 3 shows that the nature and extent of coping strategies used by the participants. During the first interview $11(4.4 \%)$ participants reported that they did not feel that they are facing life threatening diagnosis, this number reduced to $9(3.6 \%)$ in second interview and further reduced to $8(3.2 \%)$ in the third interview. On the other hand, 239(95.6\%) in the first interview reported that they were facing life threatening diagnosis which increased to 241(96.4\%) in the second and to $242(96.8 \%)$ in the third interview. During the first interview 23(9.2\%) they did not keep their line of communication open which were decreases in second $12(4.8 \%)$ and in third 14(5.6\%). On the other hand, $227(90.8 \%)$ had their lines of communication open which increased to 238(95.2\%) in second interview and reduced to $236(94.4 \%)$ in the third interview. During the first interview $11(4.4 \%)$ they did not anticipated possible physical changes which decreased in second $2(0.8 \%)$ and $4(1.6 \%)$ third interview. On the other hand, in the first interview 239(95.6\%)participants anticipated physical changes which increased to $248(99.2 \%)$ in the second interview but reduced to $246(98.4 \%)$ in the third interview.

Table 2. Cognitive levels of study participants regarding breast cancer
N=250
\begin{tabular}{l|c|c|c|c|}
\hline Cognitive Levels & Cognitive Score range & Percentage range & Freq. & Percentage \\
\hline Poor & $0-3$ & $0-30$ & 17 & 6.8 \\
\hline Average & $4-6$ & $40-60$ & 199 & 79.6 \\
\hline Good & $7-10$ & $70-100$ & 34 & 13.6 \\
\hline
\end{tabular}

Table 3. Use of coping strategies by the participants $\mathrm{N}=250$

\begin{tabular}{|c|c|c|c|c|c|c|c|c|}
\hline \multirow[t]{2}{*}{ Coping Strategy } & \multirow{2}{*}{$\begin{array}{l}\text { Scores } \\
\text { Range }\end{array}$} & \multirow{2}{*}{$\begin{array}{c}\% \\
\text { Range }\end{array}$} & \multicolumn{2}{|c|}{ Interview I } & \multicolumn{2}{|c|}{ Interview 2} & \multicolumn{2}{|c|}{ Interview 3} \\
\hline & & & Freq. & $\%$ & Freq. & $\%$ & Freq. & $\%$ \\
\hline \multirow{2}{*}{$\begin{array}{c}\text { Facing a life- } \\
\text { threatening } \\
\text { diagnosis }\end{array}$} & $1-22$ & $<50$ & 11 & 4.4 & 9 & 3.6 & 8 & 3.2 \\
\hline & $23-44$ & $>50$ & 239 & 95.6 & 241 & 96.4 & 242 & 96.8 \\
\hline \multirow{2}{*}{$\begin{array}{c}\text { Keep the lines of } \\
\text { communication } \\
\text { open }\end{array}$} & $1-8$ & $<50$ & 23 & 9.2 & 12 & 4.8 & 14 & 5.6 \\
\hline & $9-16$ & $>50$ & 227 & 90.8 & 238 & 95.2 & 236 & 94.4 \\
\hline \multirow{2}{*}{$\begin{array}{c}\text { Anticipate possible } \\
\text { physical changes }\end{array}$} & $1-26$ & $<50$ & 11 & 4.4 & 2 & 0.8 & 4 & 1.6 \\
\hline & $27-52$ & $>50$ & 239 & 95.6 & 248 & 99.2 & 246 & 98.4 \\
\hline \multirow{2}{*}{$\begin{array}{c}\text { Maintain a healthy } \\
\text { lifestyle }\end{array}$} & $1-18$ & $<50$ & 37 & 14.8 & 16 & 6.4 & 18 & 7.2 \\
\hline & $19-36$ & $>50$ & 213 & 85.2 & 234 & 93.6 & 232 & 92.8 \\
\hline \multirow{2}{*}{$\begin{array}{l}\text { Friends and family } \\
\text { help }\end{array}$} & $1-8$ & $<50$ & 18 & 7.2 & 4 & 1.6 & 6 & 2.4 \\
\hline & $9-16$ & $>50$ & 232 & 92.8 & 246 & 98.4 & 244 & 97.6 \\
\hline \multirow{2}{*}{ Fighting stigma } & $1-14$ & $<50$ & 247 & 98.8 & 247 & 98.8 & 246 & 98.4 \\
\hline & $15-28$ & $>50$ & 03 & 1.2 & 03 & 1.2 & 4 & 1.6 \\
\hline \multirow[t]{2}{*}{ Self-blame } & $1-20$ & $<50$ & 66 & 26.4 & 76 & 30.4 & 70 & 28 \\
\hline & $21-40$ & $>50$ & 184 & 73.6 & 174 & 69.6 & 180 & 72 \\
\hline \multirow[t]{2}{*}{ Religiosity } & $1-14$ & $<50$ & 174 & 69.6 & 174 & 69.6 & 182 & 72.8 \\
\hline & $15-28$ & $>50$ & 76 & 30.4 & 76 & 30.4 & 68 & 27.2 \\
\hline
\end{tabular}

During the first interview $37(14.8 \%)$ participants did not maintained their healthy lifestyle which decreased more in second interview 16(6.4\%) but increase in third interview 18(7.2\%). On the other hand, 213(85.2\%) 
participants were maintaining a healthy lifestyle in the first interview which increased in the second interview 234(93.6\%)but reduced in third interview232(92.8\%).

Table 4. Descriptive Statistics

\begin{tabular}{|l|c|c|c|}
\hline & Mean & $\begin{array}{c}\text { Std. } \\
\text { Deviation }\end{array}$ & N \\
\hline Coping Strategy in stage I & 165.96 & 10.10 & 30 \\
\hline Coping Strategy in stage II & 159.65 & 13.33 & 188 \\
\hline Coping Strategy in stage III & 147.37 & 12.98 & 32 \\
\hline
\end{tabular}

Table 5. Level of significance difference in the coping strategies of the participants in three different interviews $\mathrm{N}=250$

\begin{tabular}{|c|c|c|c|c|c|}
\hline Variable & Interview & Mean & SD & ' $t$ ' & 'p' \\
\hline \multirow{5}{*}{$\begin{array}{l}\text { Coping } \\
\text { Strategies }\end{array}$} & 1 & 1.57 & 15.65 & 5.653 & 0.000 \\
\hline & 2 & 1.60 & 13.92 & & \\
\hline & 1 & 1.57 & 15.65 & 4.325 & 0.000 \\
\hline & 3 & 1.59 & 12.87 & & \\
\hline & 2 & 1.60 & 13.92 & 2.054 & $\begin{array}{c}0.041 \\
S, p<0.05\end{array}$ \\
\hline
\end{tabular}

During the first interview 18(7.25) participants were not taking help from friends and family which decreased more in second $4(1.6 \%)$ but increased in third interview $6(2.4 \%)$. On the other hand, $232(92.8 \%)$ participants were taking help from family and friend in the first interview which increased to $246(98.4 \%)$ in the second interview but again decreased to $244(97.6 \%)$ in the third interview. During the first interview 247(98.8\%) participants did not had stigma, which was same in second interview $247(98.8 \%)$ and decreased246 (98.4\%) in third interview. On the other hand, 3(1.2\%) participants were facing the pain of stigma in first interview, which remained constant in second interview with a minimal increase to $4(1.6 \%)$ in the third interview. During the first interview 66(26.4\%) participants did not blame self for having breast cancer in first interview which increased in second interview $76(30.4 \%)$ and again decreased $70(28 \%)$ in 3rd interview. On the other hand, 184(73.6\%) participants blamed themselves for having breast cancer in the first interview which reduced to $174(69.9 \%)$ in the second interview and again increased to $180(72 \%)$ in third interview.

During the first interview 174(69.6\%) participants believed that religiosity will not help them in treatment of breast cancer, which was constant in second interview but increased $182(72.8 \%)$ in third interview. On the other hand, 76(30.4\%)participants believe that being religious will help them in treatment of breast cancer, which remained constant in second interview but reduced to $68(27.2 \%)$ in the third interview. The above table no. 3 shows that during the second session of interview which was after 1 month of first interview, the use of coping strategies had increased which reduced again in third interview. This indicates that the use of coping strategies was fluctuating. It also reveals that participants used a wide range of coping strategies to variable extent. The pattern of nature and extent of use of coping strategies shows that during the first month there is maximum utilization of coping strategies as reported in the second interview and then the use of coping strategies starts reducing as reported in the third interview.

\section{Part IV: Correlation between the stages of cancer and their coping strategies among the women having breast cancer.}

\section{Correlation for stage I,II and III breast cancer patients}

Table no. 4 shows that mean between the stage I, II and III breast cancer women's in coping strategy, comfort level score was 165.96, 159.65, 147.37 whereas Std. Deviation was $10.10,13.33$ and 12.98 respectively.

\section{Part V: Level of significance difference in the coping strategies of the participants in three different interviews}

The difference in the coping strategies was significant between first, second and third interview with $\mathrm{p}=0.000$. This reveals that the use of coping strategies was dropping over the course of disease as indicated by the reducing means values (15.65, 13.92 and 12.87 respectively for 1st, 2nd and 3rd interview).This is because of progression of disease condition and there emotion was not stable.

\section{Part VI: Association of nature of coping strategies with the demographic variables.}

The above table No. 6 shows association of coping strategies with demographic variables of the study participants. It shows that coping strategies were significantly associated with age, residence, education, occupation, monthly family income, age at menarche, marital status, age of marriage, number of children, type of family health insurance, duration of cancer, current status of cancer and line of treatment and management given to the participant as $p=0.05$. Whereas history of breast cancer in the family was not significant. This indicates that coping strategies are influenced by almost all demographic characteristics of the participants.

\section{DISCUSSION}

Coping strategies of the participants were decreased from first to second and then increased in third interview this indicates that this could be due to fast advancement of treatment they have received. Between the three interviews the coping strategies had been found inconsistent and in third interview the participants started adapting coping strategies positively for their disease and treatment. The coping strategies were found significantly associated with majority of demographic variables i.e. age, residence, 
education, occupation, monthly family income, age at menarche, marital status, age of marriage, number of children, type of family health insurance, duration of cancer, current status of cancer and treatment given to the participant as $\mathrm{p}<0.05$. This indicates that coping strategies were influenced by almost all demographic variables of the participants. This shows that as the positive emotional status were influenced by the above demographic variables, indicating that they are good source for the coping strategies.

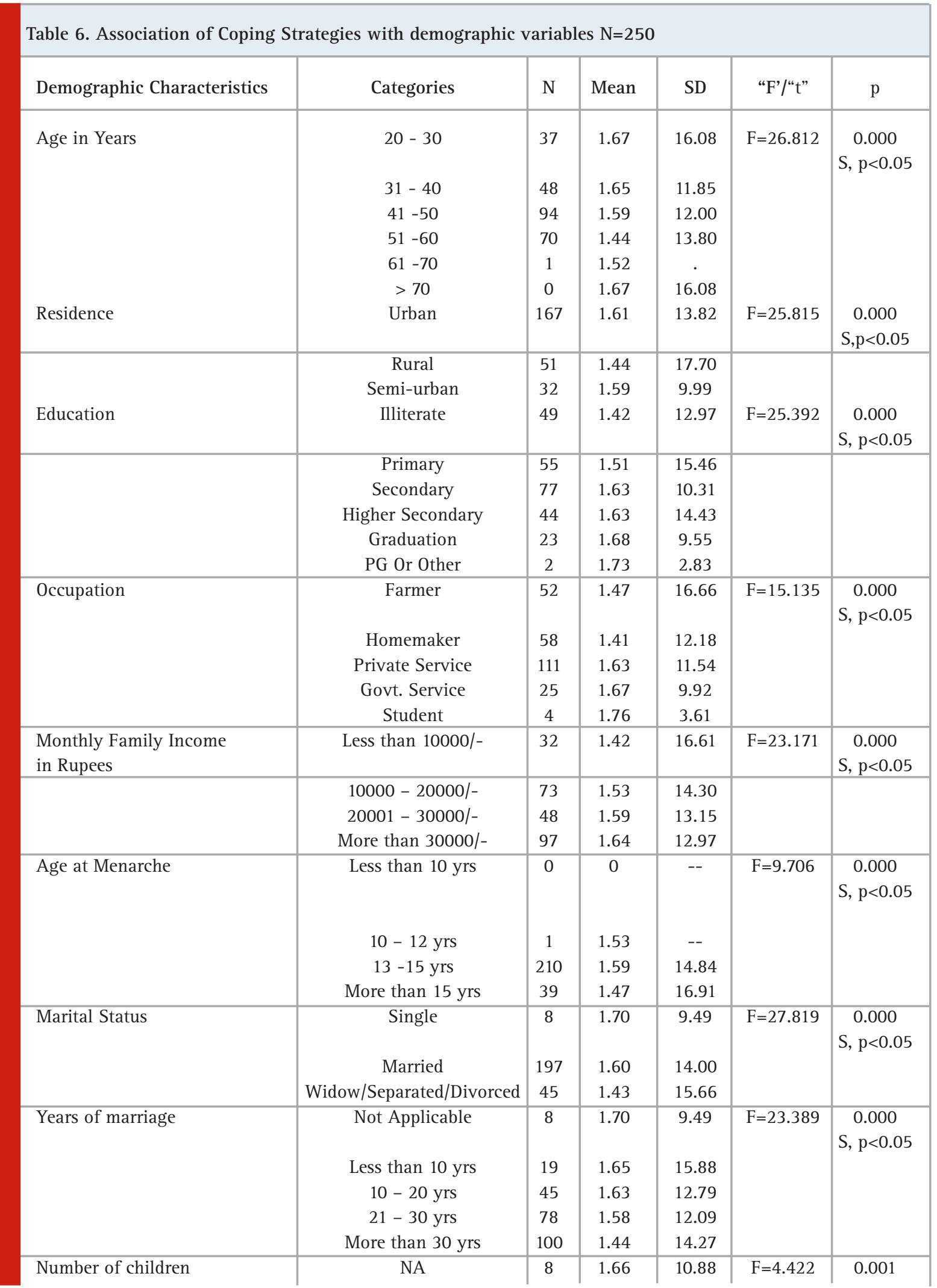




\begin{tabular}{|c|c|c|c|c|c|c|}
\hline & $\begin{array}{c}\text { Nil } \\
\text { One } \\
\text { Two } \\
\text { Three } \\
\text { More than } 3\end{array}$ & $\begin{array}{l}20 \\
48 \\
78 \\
57 \\
39\end{array}$ & $\begin{array}{l}1.54 \\
1.62 \\
1.58 \\
1.54 \\
1.51\end{array}$ & $\begin{array}{l}19.33 \\
18.98 \\
14.58 \\
13.76 \\
13.97\end{array}$ & & $\mathrm{~S}, \mathrm{p}<0.05$ \\
\hline History of Breast Feeding & $\begin{array}{c}\text { Not applicable } \\
\text { No } \\
\text { Regular } \\
\text { Irregular }\end{array}$ & $\begin{array}{c}8 \\
\\
20 \\
211 \\
11\end{array}$ & $\begin{array}{l}1.66 \\
1.69 \\
1.56 \\
1.58\end{array}$ & $\begin{array}{c}10.47 \\
-- \\
16.10 \\
11.50\end{array}$ & $F=3.263$ & $\begin{array}{c}0.022 \\
S, p<0.05\end{array}$ \\
\hline Type of Family & $\begin{array}{c}\text { Joint } \\
\text { Nuclear }\end{array}$ & $\begin{array}{l}127 \\
123 \\
\end{array}$ & $\begin{array}{l}1.58 \\
1.58 \\
\end{array}$ & $\begin{array}{l}13.54 \\
16.69\end{array}$ & $\mathrm{t}=8.200$ & $\begin{array}{c}0.000 \\
S, p<0.05\end{array}$ \\
\hline Health Insurance & $\begin{array}{l}\text { Yes } \\
\text { No }\end{array}$ & $\begin{array}{r}22 \\
228\end{array}$ & $\begin{array}{l}1.72 \\
1.56\end{array}$ & $\begin{array}{c}8.51 \\
15.45\end{array}$ & $t=22.615$ & $\begin{array}{c}0.000 \\
S, p<0.05\end{array}$ \\
\hline $\begin{array}{l}\text { History of Breast Cancer } \\
\text { in the family }\end{array}$ & $\begin{array}{l}\text { Yes } \\
\text { No }\end{array}$ & $\begin{array}{c}6 \\
244\end{array}$ & $\begin{array}{l}1.48 \\
1.57\end{array}$ & $\begin{array}{l}23.12 \\
15.42\end{array}$ & $\mathrm{t}=2.159$ & $\begin{array}{c}0.143 \\
N S, p>0.05\end{array}$ \\
\hline If yes, relationship with the patient & $\begin{array}{l}\text { Not Applicable } \\
\text { Maternal Aunt } \\
\text { Paternal Aunt } \\
\text { Granddaughter } \\
\text { Niece }\end{array}$ & $\begin{array}{l}244 \\
1 \\
2 \\
2 \\
1\end{array}$ & $\begin{array}{l}1.57 \\
1.69 \\
1.66 \\
1.21 \\
1.45\end{array}$ & $\begin{array}{c}15.42 \\
-- \\
7.07 \\
3.54 \\
--\end{array}$ & $\mathrm{F}=3.320$ & $\begin{array}{c}0.011 \\
\mathrm{~S}, \mathrm{p}<0.05\end{array}$ \\
\hline Duration of Diagnosis & $\begin{array}{l}\text { Less than one year } \\
\text { 1 }-5 \text { yrs } \\
6 \text { - } 10 \text { yrs } \\
\text { More than } 10 \text { years }\end{array}$ & $\begin{array}{c}185 \\
65 \\
0 \\
0\end{array}$ & $\begin{array}{c}1.59 \\
1.51 \\
0 \\
0\end{array}$ & $\begin{array}{c}14.74 \\
16.71 \\
-- \\
--\end{array}$ & $\mathrm{F}=13.465$ & $\begin{array}{c}0.000 \\
S, p<0.05\end{array}$ \\
\hline Current stage of Cancer & $\begin{array}{l}\text { Stage I } \\
\text { Stage II } \\
\text { Stage III }\end{array}$ & $\begin{array}{c}30 \\
188 \\
32 \\
\end{array}$ & $\begin{array}{l}1.67 \\
1.58 \\
1.43 \\
\end{array}$ & $\begin{array}{l}10.83 \\
14.81 \\
15.40\end{array}$ & $\mathrm{~F}=22.044$ & $\begin{array}{c}0.000 \\
S, p<0.05\end{array}$ \\
\hline Line of treatment and management & $\begin{array}{l}\text { Just Diagnosed \&t no } \\
\text { Treatment started } \\
\text { Only Chemo } \\
\text { Only Surgery } \\
\text { Chemo + Surgery }\end{array}$ & $\begin{array}{c}20 \\
\\
128 \\
65 \\
37\end{array}$ & $\begin{array}{l}1.60 \\
\\
1.60 \\
1.54 \\
1.49\end{array}$ & $\begin{array}{l}12.37 \\
14.94 \\
14.74 \\
18.14\end{array}$ & $F=6.505$ & $\begin{array}{c}0.000 \\
S, p<0.05\end{array}$ \\
\hline Source of information & $\begin{array}{l}\text { Mass media } \\
\text { Health professional } \\
\text { Family and friends }\end{array}$ & $\begin{array}{l}193 \\
42 \\
15\end{array}$ & $\begin{array}{l}5.35 \\
4.78 \\
5.00\end{array}$ & $\begin{array}{l}1.11 \\
1.11 \\
1.19\end{array}$ & $\mathrm{~F}=4.83$ & $\begin{array}{c}0.009 \\
S, p<0.05\end{array}$ \\
\hline
\end{tabular}

\section{REFERENCES}

Lashbrook, Mari P. Grad; Valery, Patricia C.; Knott, Vikki; Kirshbaum, Marilynne N.; Bernardes, Christina. (2018) Coping Strategies Used by Breast, Prostate, and Colorectal Cancer Survivors: A Literature Review. Cancer Nursing: September/October,Volume 41 - Issue 5 - p E23-E39

Lauver RD, Nelson CK, Vang, Rn.( 2007) Stressors And Coping Strategies Among Female Cancer Survivors After Treatments. Journal of Clinical Oncology, July;20(18): 34-38.
Nevidjon MB. Cancer Care. 1st Ed. Lippincott Publications:P.9.

Sharon A. Cook, Peter Salmon, Graham Dunn, Chris Holcombe, Philip Cornford, Peter Fisher. (2015) A Prospective Study of the Association of Metacognitive Beliefs and Processes with Persistent Emotional Distress After Diagnosis of Cancer. February, Volume 39, Issue 1, pp 51-60

Susan J. Tanner.( 1997) Social representations of cancer and their role in health promotion. Ph.D. Thesis. Department of Psychology, University of Surrey 